\title{
Sublethal predation: field measurements of arm tissue loss from the ophiuroid Microphiopholis gracillima and immunochemical identification of its predators in North Inlet, South Carolina, USA
}

\author{
P. A. Pape-Lindstrom ${ }^{1, *}$, R. J. Feller ${ }^{1,2,3}$, S. E. Stancyk ${ }^{1,2,3}$, S. A. Woodin ${ }^{1,2,3}$ \\ ${ }^{1}$ Department of Biological Sciences, ${ }^{2}$ Marine Science Program, and ${ }^{3}$ Belle W. Baruch Institute for Marine Biology and \\ Coastal Research, University of South Carolina, Columbia, South Carolina 29208, USA
}

\begin{abstract}
A daily rate of sublethal predation of arm tissue of the burrowing amphiurid brittlestar Microphiopholis gracillima (Stimpson) was determined by experimental field manipulation. A concurrent field predator survey documented the ingestion of arm tissue by invertebrate and vertebrate predators. Fish, shrimps and crabs were collected by seining and trawling in Debidue Creek, North Inlet, South Carolina, USA. Gut contents of these predators were examined both visually and immunochemically to determine presence or absence of arm tissue. Of white shrimp guts tested, $88 \%$ were positive for M. gracillima arm tissue, while $70 \%$ of blue crab guts and $39 \%$ of brown shrimp guts tested positive. Several fish species and hermit crab species were found to prey on the brittlestar arm tissue less frequently or in lesser quantities. To determine the daily sublethal predation rate, individual brittlestars of known arm length were emplaced subtidally in Debidue Creek, retrieved after either 24 or $72 \mathrm{~h}$, and then had their arm tissue remeasured. Loss of brittlestar arm tissue was statistically measurable over a $24 \mathrm{~h}$ period relative to laboratory controls. Brittlestars held for $72 \mathrm{~h}$ in the field lost 3 to 4 times more arm tissue than those exposed to predation for only $24 \mathrm{~h}$. An average daily sublethal loss rate of $20 \mathrm{~mm}$ arm tissue brittlestar ${ }^{-1}$ was calculated for the late summer/early fall perind. Trophic transfer due to sublethal predation on this individual species of brittlestar in Debidue Creek ranges between 3.3 and $9.7 \mathrm{~g} \mathrm{AFDW} \mathrm{m}^{-2} \mathrm{yr}^{-1}$, an amount equivalent to total community macrobenthic secondary production in other systems.
\end{abstract}

KEY WORDS: Sublethal predation · Ophiuroid $\cdot$ Immunoassay $\cdot$ Secondary production

\section{INTRODUCTION}

Predation usually implies death of the prey organism, followed by complete or partial consumption. However, when tissue is lost to browsing predators (termed sublethal predation by Zajac 1985), the prey organism survives the predation event. Furthermore, plants and sone invertebrates regenerate this lost tissue which then becomes available to predators at subsequent predation events. Sublethal predation occurs commonly in terrestrial and aquatic communities. Co-

-Present address: 11210 39th Drive, SE, Everett, Washington 98208, USA. E-mail: papelind@aol.com lonial organisms in coral reef communities regularly experience partial predation (Jackson \& Palumbi 1979, Harvell 1984, Lasker 1985, Harvell \& Suchanek 1987). In marine soft-sediment communities, a variety of infaunal organisms lose tissue to browsing predators, via tail or palp nipping upon polychaetes (e.g. De Vlas 1979a, b, Woodin 1984, Zajac 1985), siphon-nipping of bivalves (e.g. Trevallion 1971, Peterson \& Quammen 1982, DeVlas 1985, Zwarts \& Wanink 1989, Kamermans \& Huitema 1994), and arm consumption of brittlestars (Bowmer \& Keegan 1983, Duineveld \& Van Noort 1986). Sublethal predation has been shown to be a potentially significant source of energy flow in the few studies where it has been examined (DeVlas 1979b, 1985, O'Connor et al. 1986) 
Several studies have documented extensive tissue loss in amphiurid brittlestars collected from their native environments (Buchanan 1964, Singletary 1980, Bowmer \& Keegan 1983, Stancyk et al 1994, Sköld \& Rosenberg 1996). Arm regeneration rates and frequency of scarring in brittlestar arm populations form the basis of existing estimates of energy flow due to sublethal predation on ophiuroids (Duineveld \& Van Noort 1986, O'Connor et al. 1986). Although these estimates have been preliminary, they demonstrate that the contribution to secondary production via ophiuroid arm regeneration is ecologically important.

Arm loss in amphiurid populations has been attributed to unknown predators (Bowmer \& Keegan 1983, O'Connor et al. 1986). Although many motile invertebrates and vertebrates may ingest brittlestars or brittlestar arm tissue, most studies have focused on bottomfeeding fishes such as dab, plaice, yellowfin sole, flathead sole, and haddock as brittlestar predators (Feder \& Jewett 1981, 1987, Bowmer \& Keegan 1983, Mattson 1992, Zamarro 1992). Macerating predators, such as shrimps and crabs, have not been studied as extensively, although they are also known to ingest ophiuroids (Wassenberg \& Hill 1987, Feder \& Pearson 1988, Hill \& Wassenberg 1992). Both penaeids and crabs macerate their prey, rendering visual identification of prey in these predator guts difficult. Therefore, determination as to whether the gut contents of these macerating predators contains brittlestar arm tissue would require an immunochemical approach (sensu Feller et al. 1979, Hunter \& Feller 1987).

Microphiopholis gracillima is an infaunal amphiurid ophiuroid which lives with its small central disc buried 10 to $15 \mathrm{~cm}$ below the sediment surface. It undulates its long, slender arms to pull water through mucus-lined burrows for respiration (Woodley 1975). Amphiurid brittlestars are selective deposit and/or suspension feeders (Buchanan 1964, Clements \& Stancyk 1984) and usually have 3 of their 5 arms extended upon the surface for feeding and respiration (authors' pers. obs.). Singletary (1980) reported a density of $56 \mathrm{~m}^{-2}$ for this species in Biscayne Bay, Florida, USA, and in Debidue Creek, North Inlet, South Carolina, USA, the natural subtidal density of these brittlestars is $35 \mathrm{~m}^{-2}$ (Stancyk unpubl. data). A 12 mo arm scar survey conducted on brittlestars collected in North Inlet found that $85 \%$ of the $2405 \mathrm{M}$. gracillima arms examined had at least 1 regeneration scar. Only $3 \%$ of the 675 individual brittlestars examined bore no discernible arm scars (Stancyk et al. 1994). Again, the scarring was attributed to unknown predators.

Existing studies of energy flow resulting from sublethal predation on ophiuroids lack information concerning both identification of the local predators and their grazing rates on the brittlestar arms. After mea- suring laboratory ingestion rates (Pape-Lindstrom 1994), the goals of the present study were: (1) to learn which local predators graze Microphiopholis gracillima arm tissue in North Inlet; (2) to measure field loss rates of brittlestar arm tissue due to grazing by natural predators; (3) to compare loss rates in the field with those due to white shrimp predation in the laboratory; and (4) to determine the relative importance of the sublethal predation in terms of trophic energy flow.

\section{MATERIALS AND METHODS}

Individual core emplacement field experiments. Microphiopholis gracillima were collected during low tide from a shallow, subtidal mudflat in Debidue Creek, North Inlet $\left(37^{\circ} 20^{\prime} \mathrm{N}, 79^{\circ} 10^{\prime} \mathrm{W}\right)$ and transported by boat to the Baruch Field Laboratory, Georgetown, South Carolina. There, brittlestars were held in an aerated aquarium with a salinity of approximately $30 \%$ prior to use. Next, brittlestars were anesthetized in a $1: 1$ mixture of $35 \% \mathrm{MgCl}_{2}$ and seawater, and relaxed individuals were placed in a large shallow petri dish, oral side up. Arms of each brittlestar were straightened with. forceps and their lengths measured to the nearest $\mathrm{mm}$ from the point at which the arm joins the oral frame, to the arm tip. The oral diameter of the brittlestar was measured as described in Singletary (1980), using an ocular micrometer mounted in a dissecting microscope (mag. 24x). If ripe gonads were present, the sex of the individual was also noted.

After being measured, brittlestars were allowed to burrow in individual gray polyvinyl chloride (PVC) cores (inside diameter $=5 \mathrm{~cm}$, length $=9 \mathrm{~cm}$ ). The cores contained sieved (mesh $=3 \mathrm{~mm}$ ) mud from the subtidal field collection site and were covered on the bottom with Nitex mesh $($ mesh $=0.39 \mathrm{~mm}$ ) and on the top with fiberglass window screen (mesh $=1.1 \mathrm{~mm}$ ) or Nitex mesh (see Table 1). The cores were held upright in an aerated fiberglass tank $(2 \times 0.5 \times 0.5 \mathrm{~m})$, until the following low tide. This $12 \mathrm{~h}$ h.olding time allowed the brittlestars to recover from anesthetization and become established in their subsurface burrows inside the cores

Each brittlestar was assigned randomly to 1 of 3 treatments: laboratory control, field control or field treatment. The laboratory control cores were held in an aerated fiberglass tank in the indoor seawater laboratory for the duration of the experiment. The water temperature was maintained at approximately $25^{\circ} \mathrm{C}$. The brittlestars in laboratory contro] cores were given a boat ride to the field study site during deployment of field cores, to mimic as closely as possible the handling stresses of the field-deployed brittlestars. 
At low tide the field control and field treatment cores were emplaced in the creek bottom with the core tops flush with the sediment surface, using a modified flower bulb planter to create appropriately sized holes. The cores were arrayed in a square grid $(n=18$ to 24 for each treatment; see Table 1), with brittlestars in alternating treatment and field control cores spaced about $30 \mathrm{~cm}$ apart within the grid. The grid was situated below the low tide line approximately $10 \mathrm{~m}$ from the water's edge in a subtidal mudflat where the natural brittlestar population occurs. At absolute low tide the area was covered by about $10 \mathrm{~cm}$ of water. The field control cores retained the Nitex top coverings, while the field treatment cores had the Nitex top covering removed, thus allowing predators access to brittlestar arm tips. All cores retained the Nitex bottom covering.

On the 2 experimental dates, 2 arrays of cores were emplaced side by side, with one set of cores being retrieved after $24 \mathrm{~h}$ and the other after $72 \mathrm{~h}$ (Table 1). After retrieval from the field, the brittlestars were returned to the field laboratory, carefully removed from their cores and arms and oral diameters were measured again. The mud in each core was carefully sieved to recover any arm fragments which the brittlestars may have autotomized. The total amount of arm tissue lost was calculated for each individual brittlestar.

Field predator surveys. Collection of potential predators: Survey collections consisted of seining for flatfishes, crabs and shrimps in the area of Debidue Creek where the brittlestars occur. Field collections were conducted intermittently from 1990 to 1992, with several day and night collections made during the deployment of PVC cores for the arm loss rate experiment in 1992. In all cases, upon capture the predators were immediately frozen on dry ice, returned to the laboratory in Columbia, South Carolina and stored frozen at $-70^{\circ} \mathrm{C}$ until dissection.

Collection of predator gut contents: Potential predators were identified to species level and their foreguts removed. Gut contents of each predator were examined visually under a dissecting microscope and then placed in individual $1.5 \mathrm{ml}$ microcentrifuge tubes. The dissections were performed carefully to avoid contaminating the gut contents with body tissues or tissue from the digestive tract of the predator. The gut contents were homogenized using a glass stirring rod with TES buffer (5 mM N-tris [hydroxymethyl] methyl-2aminoethane sulfonic acid, $30 \mathrm{mM} \mathrm{NaOH}$ and $150 \mathrm{mM}$ $\mathrm{NaCl}, \mathrm{pH}$ 7.3). (The volume of buffer used was $100 \mu \mathrm{l}$ for each white shrimp and brown shrimp Penaeus aztecus gut content sample, which were usually similar in body size and gut content volume. Buffer was added in a 1:1 gut content weight/TES volume ratio for all other species of predators.) During processing, the predators and their gut contents were kept on ice to
Table 1. Dates, number of replicates ( $n$ ) and descriptions of field and laboratory treatments performed. top/bottom: type of covering on the top and bottom of individual PVC cores; nc: not covered; ws: fiberglass window screen, mesh size $=1.1 \mathrm{~mm}$; ntx: Nitex, mesh size $=0.39 \mathrm{~mm}$

\begin{tabular}{|c|c|c|c|c|}
\hline Date & Covering & $\begin{array}{c}\text { Lab } \\
\text { control } \\
n\end{array}$ & $\begin{array}{c}\text { Field } \\
\text { predation } \\
\mathrm{n}\end{array}$ & $\begin{array}{c}\text { Total } \\
\mathrm{n}\end{array}$ \\
\hline \multicolumn{5}{|l|}{24 h duration } \\
\hline \multirow[t]{3}{*}{29 Aug 1992} & & 23 & 23 & 46 \\
\hline & top & wS & nc & \\
\hline & bottom & $n t x$ & $\overline{n t x}$ & \\
\hline \multirow[t]{3}{*}{25 Sep 1992} & & 18 & 18 & 36 \\
\hline & top & $n t x$ & nc & \\
\hline & bottom & $n+x$ & $\overline{\mathrm{ntx}}$ & \\
\hline \multicolumn{5}{|l|}{$72 \mathrm{~h}$ duration } \\
\hline \multirow[t]{3}{*}{29 Aug 1992} & & 25 & 24 & 49 \\
\hline & top & ws & $\mathrm{nc}$ & \\
\hline & bottom & $\overline{n t x}$ & $\overline{n t x}$ & \\
\hline \multirow[t]{3}{*}{25 Sep 1992} & & 19 & 23 & 42 \\
\hline & top & $n t x$ & $n c$ & \\
\hline & bottom & nix & $n t x$ & \\
\hline
\end{tabular}

avoid further digestion of prey proteins. The predator gut contents were stored at $-70^{\circ} \mathrm{C}$ until later immunoassay.

Immunoassay of predator gut contents: Polyclonal antiserum raised to soluble proteins from the arm tissue of Microphiopholis gracillima was used to assay predator gut contents following the micro-Ouchterlony technique (Feller et al. 1979). To test for the presence of brittlestar arm tissue in the gut content samples, the following spatial arrangement of samples on the immunoassay template was employed: the center well contained the anti-brittlestar arm tissue antiserum, wells 1 and 4 contained homologous brittlestar arm tissue antigen and wells 2 and 3 contained solubilized gut contents of 2 individual predators. Formation of 2 or more lines of identity (precipitin bands) between the wells containing predator gut contents and the wells containing the homologous brittlestar arm antigen was scored as 'positive' for the presence of $M$. gracillima arm tissue (Fig. 1). The criterion of at least 2 identity bands was chosen because, of the echinoderm species present in North Inlet, only the brittlestar Ophiothrix angulata (which does not occur in the mudflat area where predators were collected) formed more than 2 precipitin bands with the anti-M. gracillima antiserum (Pape-Lindstrom 1994). 


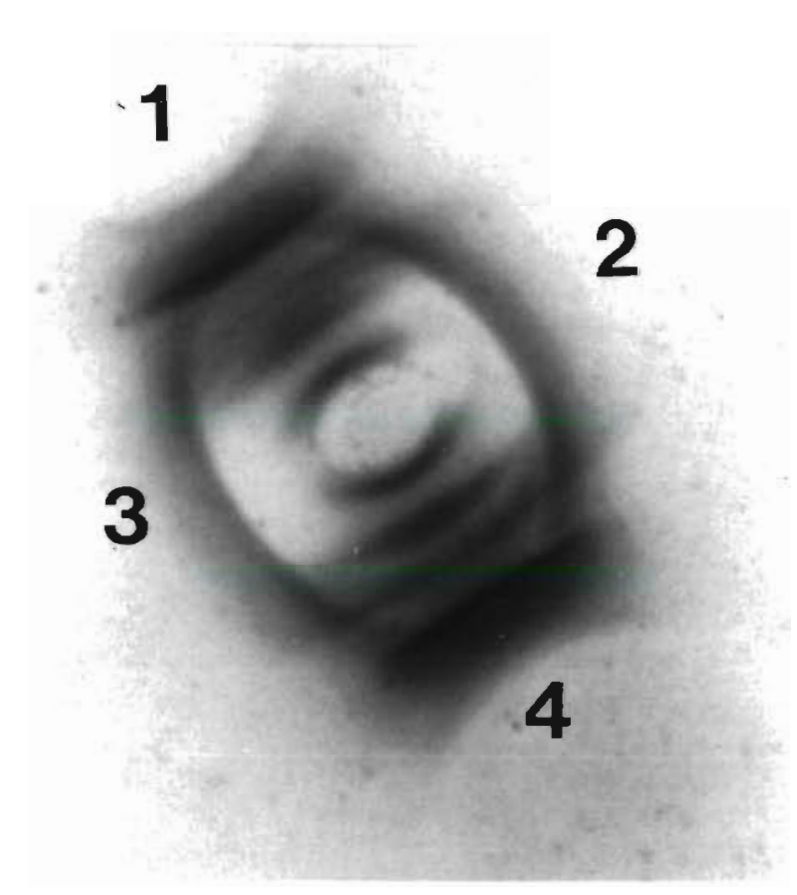

Fig. 1. Slide of micro-Ouchterlony immunoassay with anti $-M$. gracillima in center well, brittlestar arm protein in wells 1 and 4 (self-reaction), and predator gut contents in wells 2 and 3. Formation of 2 or more identity bands between the wells containing predator gut contents and the wells containing the brittlestar arm protein was scored as 'positive'

Data analysis. Due to the high silt load in Debidue Creek, the Nitex (mesh $=0.39 \mathrm{~mm}$ ) used to prevent exposure of control brittlestar arms became clogged (authors' pers. obs.) and may have caused less than optimal dissolved oxygen conditions in the field control cores. This suffocation effect was most pronounced in the $72 \mathrm{~h}$ trial of 29 August, in which 6 brittlestars in the Nitex-covered field control cores had experienced death and decay by the end of the experiment. Consequently, data from brittlestars held in the field control cores had to be excluded from the data analysis. Smaller mesh Nitex was used in these experiments because brittlestars were observed to extend their arms through both top and bottom screen (mesh $=1.1 \mathrm{~mm}$ ) used in preliminary experiments. Although the larger mesh window screen did not seem to produce such a pronounced suffocation effect, it could not serve as an effective control because brittlestar arm tips were still available to predators.

The parameter of interest - total length of arm tissue lost by an individual brit- tlestar - was $\log _{10}$ transformed to comply with the assumptions of ANOVA (homoscedasticity). When factors such as gonad color (gender) of brittlestar or placement in the field array by row, column, or edge position (brittlestars in an outermost row or column were considered to be in an edge position) were found to be insignificant in preliminary data analyses, the factors were eliminated from the final ANOVA model to increase the degrees of freedom and simplify interpretation. Because all means presented in the figures and tables are back-transformed means, 95\% confidence intervals are asymmetric. All statistical analyses presented were performed on transformed data using SAS/STAT for the personal computer (SAS Institute 1988).

\section{RESULTS}

\section{Individual core emplacement field experiments}

A 2-factor ANOVA model with interactions was used to compare arm tissue losses by date and treatment from 29 August and 25 September on which both 24 and $72 \mathrm{~h}$ trials were performed. Treatment was highly significant $(\mathrm{p}=0.0001, F=30.75, \mathrm{MS}=$ 9.57, $\mathrm{df}=3$ ). Neither date nor the date $\times$ treatment interaction was significant $(\mathrm{p}=0.12, F=2.47, \mathrm{MS}=$ 0.77, $\mathrm{df}=1$ and $\mathrm{p}=0.36, F=1.07, \mathrm{MS}=0.33, \mathrm{df}=3$, respectively).

A Tukey's multiple comparison of means by treatment found that the mean amount of arm tissue lost

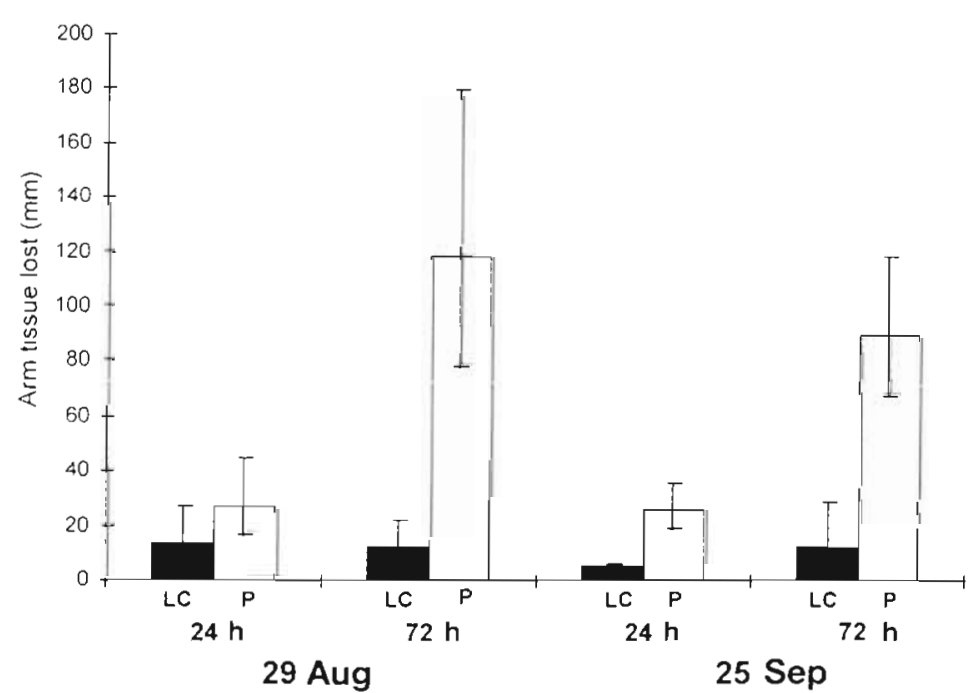

Fig. 2. Back-transformed mean length of arm tissue lost by an individual brittlestar on the dates for which both 24 and $72 \mathrm{~h}$ core emplacement trials were conducted. LC: lab control cores; P: field treatment cores in which brittlestars were exposed to predation. Error bars represent $95 \%$ confidence limits 
Table 2. Complete listing of predators' guts subjected to immunoassays. Organized by species, date, and time of collection

\begin{tabular}{|c|c|c|c|c|c|}
\hline Species & Capture date & Time & $\begin{array}{l}\text { Number } \\
\text { assayed }\end{array}$ & $\begin{array}{l}\text { Number } \\
\text { positive }\end{array}$ & $\begin{array}{l}\text { Percent } \\
\text { positive }\end{array}$ \\
\hline $\begin{array}{l}\text { Penaeus setiferus } \\
\text { white shrimp }\end{array}$ & $\begin{array}{l}20 \text { Aug } 1990 \\
30 \text { Aug } 1992 \\
31 \text { Aug } 1992\end{array}$ & $\begin{array}{l}\text { Day } \\
\text { Day } \\
\text { Night }\end{array}$ & $\begin{array}{r}57 \\
8 \\
27\end{array}$ & $\begin{array}{r}51 \\
4 \\
26\end{array}$ & $\begin{array}{l}89 \\
50 \\
96\end{array}$ \\
\hline $\begin{array}{l}\text { Penaeus aztecus } \\
\text { brown shrimp }\end{array}$ & $\begin{array}{l}\text { 30 Jun } 1992 \\
\text { 30 Aug } 1992 \\
\text { 31 Aug } 1992\end{array}$ & $\begin{array}{l}\text { Night } \\
\text { Day } \\
\text { Night }\end{array}$ & $\begin{array}{r}14 \\
1 \\
8\end{array}$ & $\begin{array}{l}4 \\
1 \\
4\end{array}$ & $\begin{array}{r}29 \\
100 \\
50\end{array}$ \\
\hline $\begin{array}{l}\text { Callinectes sapidus } \\
\text { blue crab }\end{array}$ & $\begin{array}{l}5 \text { Feb } 1992 \\
30 \text { Jun } 1992 \\
\text { 30 Jun } 1992 \\
\text { 30 Aug } 1992\end{array}$ & $\begin{array}{l}\text { Day } \\
\text { Day } \\
\text { Night } \\
\text { Day }\end{array}$ & $\begin{array}{r}7 \\
13 \\
9 \\
1\end{array}$ & $\begin{array}{r}0 \\
12 \\
9 \\
0\end{array}$ & $\begin{array}{r}0 \\
92 \\
100 \\
0\end{array}$ \\
\hline $\begin{array}{l}\text { Pagurus spp. or } \\
\text { Clibanarius spp. } \\
\text { hermit crab }\end{array}$ & $\begin{array}{l}5 \text { Feb } 1992 \\
30 \text { Jun } 1992 \\
31 \text { Aug } 1992 \\
26 \text { Sep } 1992\end{array}$ & $\begin{array}{l}\text { Day } \\
\text { Day } \\
\text { Night } \\
\text { Day }\end{array}$ & $\begin{array}{l}1 \\
6 \\
1 \\
1\end{array}$ & $\begin{array}{l}0 \\
4 \\
0 \\
0\end{array}$ & $\begin{array}{r}0 \\
67 \\
0 \\
0\end{array}$ \\
\hline $\begin{array}{l}\text { Leiostomus xanthurus } \\
\text { spot }\end{array}$ & $\begin{array}{l}30 \text { Jun } 1992 \\
30 \text { Aug } 1992 \\
31 \text { Aug } 1992\end{array}$ & $\begin{array}{l}\text { Night } \\
\text { Day } \\
\text { Night }\end{array}$ & $\begin{array}{r}10 \\
3 \\
5\end{array}$ & $\begin{array}{l}2 \\
0 \\
3\end{array}$ & $\begin{array}{r}20 \\
0 \\
60\end{array}$ \\
\hline $\begin{array}{l}\text { Bairdiella chrysoura } \\
\text { silver perch }\end{array}$ & $\begin{array}{l}30 \text { Aug } 1992 \\
31 \text { Aug } 1992\end{array}$ & $\begin{array}{l}\text { Day } \\
\text { Night }\end{array}$ & $\begin{array}{r}14 \\
6\end{array}$ & $\begin{array}{l}6 \\
0\end{array}$ & $\begin{array}{r}43 \\
0\end{array}$ \\
\hline $\begin{array}{l}\text { Lagodon rhomboides } \\
\text { pinfish }\end{array}$ & $\begin{array}{l}30 \text { Jun } 1992 \\
30 \text { Aug } 1992 \\
31 \text { Aug } 1992\end{array}$ & $\begin{array}{l}\text { Night } \\
\text { Day } \\
\text { Night }\end{array}$ & $\begin{array}{l}4 \\
2 \\
6\end{array}$ & $\begin{array}{l}1 \\
0 \\
0\end{array}$ & $\begin{array}{r}25 \\
0 \\
0\end{array}$ \\
\hline $\begin{array}{l}\text { Anchod mitchilli } \\
\text { bay anchovy }\end{array}$ & $\begin{array}{l}30 \text { Jun } 1992 \\
30 \text { Aug } 1992 \\
31 \text { Aug } 1992\end{array}$ & $\begin{array}{l}\text { Night } \\
\text { Day } \\
\text { Night }\end{array}$ & $\begin{array}{r}5 \\
5 \\
11\end{array}$ & $\begin{array}{l}0 \\
0 \\
0\end{array}$ & $\begin{array}{l}0 \\
0 \\
0\end{array}$ \\
\hline $\begin{array}{l}\text { Fundulus heteroclitus } \\
\text { mummichog }\end{array}$ & 5 Feb 1992 & Day & 4 & 0 & 0 \\
\hline $\begin{array}{l}\text { Fundulus majalis } \\
\text { killifish }\end{array}$ & 5 Feb 1992 & Day & 5 & 0 & 0 \\
\hline $\begin{array}{l}\text { Mugil spp. } \\
\text { mullet }\end{array}$ & 30 Jun 1992 & Night & 10 & 1 & 10 \\
\hline $\begin{array}{l}\text { Synodus foetens } \\
\text { lizard fish }\end{array}$ & 30 Jun 1992 & Night & 3 & 0 & 0 \\
\hline $\begin{array}{l}\text { Citharichthys spilopterus } \\
\text { bay whiff }\end{array}$ & 30 Jun 1992 & Night & 3 & 0 & 0 \\
\hline $\begin{array}{l}\text { Symphurus plagiusa } \\
\text { blackcheek tonguefish }\end{array}$ & 30 Jun 1992 & $\begin{array}{l}\text { Day } \\
\text { Night }\end{array}$ & $\begin{array}{l}1 \\
2\end{array}$ & $\begin{array}{l}0 \\
0\end{array}$ & $\begin{array}{l}0 \\
0\end{array}$ \\
\hline $\begin{array}{l}\text { Paralichthys lethostigma } \\
\text { southern flounder }\end{array}$ & 30 Jun 1992 & $\begin{array}{l}\text { Day } \\
\text { Night }\end{array}$ & $\begin{array}{l}1 \\
1\end{array}$ & $\begin{array}{l}0 \\
0\end{array}$ & $\begin{array}{l}0 \\
0\end{array}$ \\
\hline $\begin{array}{l}\text { Etropus crossotus } \\
\text { fringed flounder }\end{array}$ & 30 Jun 1992 & Night & 2 & 0 & 0 \\
\hline
\end{tabular}

by brittlestars in laboratory control cores held for either 24 or $72 \mathrm{~h}$ was not different, but was significantly lower than mean arm tissue lost from brittlestars in field predation treatment cores emplaced for either 24 or $72 \mathrm{~h}$ (Fig. 2). For treatment cores emplaced in the field, arm tissue loss was significantly greater from brittlestars in the $72 \mathrm{~h}$ cores versus the $24 \mathrm{~h}$ cores for both experimental dates (Fig. 2). On 29 August, the brittlestars in field treatment cores lost 4.3 times as much arm tissue in $72 \mathrm{~h}$ vs $24 \mathrm{~h}$. For the 25 September experiment, brittlestars in field treatment cores lost 3.4 times as much arm tissue in $72 \mathrm{~h}$ as they lost in $24 \mathrm{~h}$ (Fig. 2).

\section{Immunochemical analyses of predator gut contents}

White shrimp Penaeus setiferus were the most abundant potential predator captured and $88 \%$ of all guts tested ( $n=92$ ) were positive for the presence of brittlestar arm proteins (Table 2). Ogburn et al. (1988) found spot Leiostomus xanthurus to be the second most abundant species in North Inlet, comprising $19 \%$ of the total catch in their 4 yr census. Of the spot captured for this study, $28 \%$ or 5 of 18 tested positive for brittlestar arm tissue. Thirty-nine percent, or 9 of 23 , of the brown shrimp $P$. aztecus guts tested were positive. 
Another important macerating predator, the blue crab Callinectes sapidus, had a $70 \%$ positive response of guts tested (21 of 30 ).

None of the 7 flatfish gut content samples had a positive response to brittlestar arm protein. This was somewhat unexpected, as several species of flatfish are known as brittlestar predators in other areas of the world (see 'Introduction'). However, all of the predator samples (except for 5 February 1992) were collected by seining and this is not the most effective method for capturing flatfish. A study designed to specifically address whether flatfish in North Inlet feed on brittlestars would require use of a beam trawl designed for muddy sediment and a much larger sample size of fish.

The goals of this study included a survey of local potential predators of brittlestar arm tissue. As a consequence, many of the sample sizes for each type of predator were quite small and did not allow comparisons to be made across size classes of a species, or to compare day and night differences in feeding. Also day versus night differences in predator feeding would be difficult to detect without extensive knowledge of gut clearance times for each predator species. Now that individual species of shrimp, crabs, and fish have been identified as brittlestar predators, future research projects could be designed to address these more specific questions.

\section{DISCUSSION}

We have documented predation by a variety of vertebrate and invertebrate predators upon a single species of a burrowing amphiurid brittlestar. Stancyk et al. (1994) established that arm loss events in the North Inlet population of Microphiopholis gracillima were very common and attributed this arm tissue loss to unknown predators. This study clearly demonstrates that white shrimp and blue crabs are important predators of this brittlestar in North Inlet, whereas brown shrimp, hermit crabs and other fishes prey on the brittlestars less frequently or in lesser amounts (Table 2). The major sublethal predators are macerating invertebrate organisms which are also abundant and commercially valuable. Additionally, our research provides new quantitative information on sublethal predation rates upon brittlestar arm tissue in the field. Such information is not only important for specifically understanding the role of brittlestars in benthicpelagic coupling, but also for perceiving the significance of the general phenomenon of sublethal predation in marine environments.

Presence of brittlestar arm protein in the guts of field-collected predators supports the hypothesis that the arm tissue missing in the core emplacement study was lost to predation. The increase in arm tissue loss seen from 24 to $72 \mathrm{~h}$ was approximately linear, with a slightly more than 3-fold increase observed (Fig. 2) A loss rate of $20 \mathrm{~mm}$ brittlestar ${ }^{-1} \mathrm{~d}^{-1}$ of brittlestar arm tissue was calculated [mean arm loss rates from field predation cores from the 24 and 72 h trials on both 29 August and 25 September ( $31 \mathrm{~mm}$ ) minus the mean arm loss from all laboratory control brittlestars (11 $\mathrm{mm}$ ) for the same dates]. This is one of very few studies to measure a daily sublethal predation loss rate for an invertebrate species of prey (for other approaches see Harvell 1984, Zajac 1995).

Interestingly, the 3 most important species of brittlestar predators, white shrimp, blue crabs, and brown shrimp, are all macerating predators of considerable economic importance (Theiling 1988). A variety of sublethal predation studies have focused on fish predators, whose gut contents are more easily identified with visual analysis, but have overlooked macerating predators (see 'Introduction'). In other areas of known high brittlestar density such as Mississippi Sound, Alabama, USA, where the congeneric Microphiopholis atra occurs at densities from 100 to $1382 \mathrm{~m}^{-2}$ (US Corps of Engineers 1982, Valentine 1991), these burrowing brittlestars may also be an important food source for the commercially valuable penaeid shrimps.

Unlike penaeid shrimps, blue crabs are present in North Inlet year round. No ingestion of brittlestar arm tissue was detectable in the smaller crabs collected in the winter (Table 2). This could be due to either ontogenetic or seasonal shifts in diet for the blue crab, or to shorter gut contact times for the smaller crabs. Alternatively, it may indicate that brittlestars are inactive, with their arms withdrawn into their burrows, and thus not available for predation. Hendler (1973) and Stancyk (pers. obs.) have found amphiurids to be inactive in the winter. Overall, large proportions of the blue crabs present in Debidue Creek ingested brittlestar arm tissue during the summer months.

The field loss rate of $20 \mathrm{~mm} \mathrm{~d}^{-1}$ is approximately 1 order of magnitude lower than the laboratory loss rate of $240 \mathrm{~mm}$ brittlestar $^{-1} \mathrm{~d}^{-1}$ (Pape-Lindstrom 1994). This was the rate at which previously starved shrimp at high densities were able to ingest brittlestars which had access to a sediment refuge in the laboratory. An even greater loss rate of $80 \mathrm{~mm}$ arm tissue $\mathrm{h}^{-1}$ (1920 $\mathrm{mm} \mathrm{d}^{-1}$ ) was seen in the laboratory when shrimp were allowed to graze on brittlestars denied a sediment refuge.

The average-sized brittlestar used in these experiments, with a total arm length of about $450 \mathrm{~mm}$ of arm tissue, would lose all of its arm tissue in about $25 \mathrm{~d}$ at the sublethal predation rate of $20 \mathrm{~mm} \mathrm{~d}^{-1}$. However, Microphiopholis gracillima regenerates fairly rapidly in the summer months and is capable of regenerating up to $3 \%$ of its arm weight per day (Stancyk et al. 
1994). The $20 \mathrm{~mm} \mathrm{~d}^{-1}$ arm loss represents ca $4 \%$ of the total arm tissue of an 'average brittlestar' $450 \mathrm{~mm}$ of total arm tissue). Therefore, the brittlestars in North Inlet can probably regenerate arm tissue almost as rapidly as it is lost to sublethal predation.

The sublethal loss rate $\left(20 \mathrm{~mm} \mathrm{~d}^{-1}\right)$ is realistic only for the season during which these experiments were performed, namely summer and early fall. The summer months are the time of greatest predator abundance in North Inlet (Ogburn et al. 1988), as well as the fastest regeneration rates of ophiuroids (Stancyk et al. 1994). Therefore, the loss rate is probably much lower or even zero during colder months. This is supported by results from the 5 February 1992 predator collection from which no gut contents tested positive for brittlestar arm protein (Table 2). Care must also be taken in extrapolating these sublethal predation rates to populations of infaunal brittlestars which live in different environments. For example, Ophiophragmus filograneus in seagrass beds in Tampa Bay, Florida, USA, were found to experience no arm loss in control (unamputated) brittlestars held in topless cages for a $14 \mathrm{~d}$ experiment (Clements et al. 1994). Additionally, a recent survey of arm scarring incidence seemed to indicate that brittlestar habitat preference and/or trophic mode was correlated to scarring frequency (Sköld \& Rosenberg 1996).

Stancyk et al. (1994) speculated that decreased activity by grazed brittlestars contributed to the significant variation in arm scarring seen between individual brittlestars. Ophiuroid studies by Clements (1985), Bourgoin (1987) and S. M. Lindsay (pers. comm.) support the decreased activity hypothesis Brittlestars are probably not nutritionally limited in North Inlet (see Stancyk et al. 1994 for further discussion) and therefore can afford to spend less time with their arms on the surface (i.e. feeding) in response to arm tip loss. Reduced siphon exposure in the pres. ence of the brown shrimp Crangon crangon has also been reported for the bivalve Macoma balthica (Kamermans \& Huitema 1994).

White shrimp are present in North Inlet for about $130 \mathrm{~d}$ each year. Shrimp typically enter the estuary by mid to late June and remain through mid November (based on a bi-weekly 10 yr seine survey; Baruch Institute unpubl. data). Microphiopholis gracillima occur in one area of North Inlet at a density of approximately $35 \mathrm{~m}^{-2}$ (Stancyk unpubl. data). The following calculations include a factor of $10.7 \mathrm{mg} / 100 \mathrm{~mm}$ to convert from arm length to AFDW (100 mm brittlestar arm tissue $=10.7 \pm 2.92 \mathrm{mg} \mathrm{AFDW}$; ashed at $400^{\circ} \mathrm{C}$; data from Pape-Lindstrom 1994), and yield the high end of the range for estimated annual energy transfer due to sublethal predation by penaeid shrimp on $M$. gracillima arm tissue in North Inlet:

$$
\begin{gathered}
20 \mathrm{~mm} \mathrm{~d}^{-1} \mathrm{bs}^{-1} \times 35 \mathrm{bs} \mathrm{m}^{-2} \times 130 \mathrm{~d} \\
=91000 \mathrm{~mm} \text { arm tissue } \mathrm{m}^{-2} \mathrm{yr}^{-1} \\
(130 \mathrm{~d}=\text { days of penaeid predator abundance } \\
\text { in North Inlet }) \\
91000 \mathrm{~mm} \times(10.7 \mathrm{mg} / 100 \mathrm{~mm}) \times(1 \mathrm{~g} / 1000 \mathrm{mg}) \\
=9.7 \mathrm{~g} \text { AFDW lost } \mathrm{m}^{-2} \mathrm{yr}^{-1}
\end{gathered}
$$

where bs = brittlestar.

The calculation of the low end of the range is based on changing 2 of the assumptions used above. First, days of penaeid abundance was decreased by half to account for lower feeding rates of smaller shrimp present during the early part of their estuarine nursery season $\left(20 \mathrm{~mm} \mathrm{~d}^{-1}\right.$ loss rate is based on feeding of larger shrimp in August and September). Second, we invoked the above described decreased activity hypothesis (Stancyk et al. 1994) and lowered the density of brittlestars with arm tips available to predators to $24 \mathrm{~m}^{-2}$ (assuming no activity for $31 \%$ of brittlestars collected with 2 or more broken arm tips; S. E. Stancyk, H. M. Golde \& P. A. Pape-Lindstrom unpubl. data). Changing these 2 assumptions yielded a lower value of $3.3 \mathrm{~g}$ AFDW m $\mathrm{m}^{-2} \mathrm{yr}^{-1}$ of annual trophic transfer due to sublethal grazing by shrimp and other predators on $\mathrm{Mi}$ crophiopholis gracillima arm tissue in North Inlet.

The mid-point of the estimated range is $6.5 \mathrm{~g}$ AFDW $\mathrm{m}^{-2} \mathrm{yr}^{-1}$ of trophic transfer This is comparable to other estimates of macrobenthos consumption by predatory epibenthic fauna or estimates of overall community secondary production calculated for similar mudflat areas (Table 3; see also Table 3, Maurer et al. 1992 for estimates from other sediment types). The published estimates are for total consumption summed over all species of epibenthic predators or for secondary production for all species of the infauna, as opposed to partial predation upon one species, as in the present estimate.

Sköld et al. (1994) made a single point estimate of total secondary production by an Amphiura filiformis population with a density of $280 \mathrm{~m}^{-2}$ in the Skagerrak, west $S$ weden. They found tota] secondary production to be $2.59 \mathrm{~g}$ AFDW $\mathrm{yr}^{-1},(\mathrm{P} / \mathrm{B}=0.46)$ and estimated (p. 89 ) that about $22 \%$ of total brittlestar biomass was lost to cropping by predators. Using these data, we calculated that the $A$. filiformis population contributes $1.24 \mathrm{~g} \mathrm{AFDW} \mathrm{m}^{-2} \mathrm{yr}^{-1}$ to trophic transfer via sublethal predation. Significantly less annual trophic transfer may be occurring in the $A$. filiformis community than in the North Inlet Microphiopholis gracillima community ( 1.24 vs $6.5 \mathrm{~g} \mathrm{AFDW} \mathrm{m}^{-2} \mathrm{yr}^{-1}$ ), especially when one considers that $A$. filiformis has a regeneration rate more than an order of magnitude less than $M$. gracillima $\left[A\right.$. filiformis rate $=0.0048 \mathrm{mg}$ dry weight $\mathrm{d}^{-1}$ (Andreasson as cited in Sköld et al. 1994); using conversion factors from Josefson \& Jensen (1992) yields a rate 
Table 3. Estimates of epibenthic consumption and secondary production in soft sediments

\begin{tabular}{|c|c|c|c|c|}
\hline & Conditions & Location & Year & Source \\
\hline \multicolumn{5}{|l|}{$\begin{array}{l}\text { Epibenthic } \\
\text { consumption } \\
\left(\text { g AFDW m } \mathrm{m}^{-2} \mathrm{yr}^{-1}\right)\end{array}$} \\
\hline 26 & Sandy-silt ${ }_{i}<1 \mathrm{~m}$ & Gullmarstjord, Sweden & 1978 & Pihl (1985) \\
\hline 9.1 & Sandy-silt $;<1 \mathrm{~m}$ & Gullmarsfjord, Sweden & 1977 & Moller et al. (1985) \\
\hline 11.8 & & & 1978 & \\
\hline 11.2 & & & 1979 & \\
\hline 9.4 & & & 1980 & \\
\hline 10.1 & & & 1981 & \\
\hline 7 & & & 1982 & \\
\hline 6.5 & Mudi $_{i}<1 \mathrm{~m}$ & North Inlet, South Carolina, USA & 1994 & Present study \\
\hline \multicolumn{5}{|l|}{$\begin{array}{l}\text { Secondary } \\
\text { production } \\
\left(\mathrm{g} \text { AFDW m } \mathrm{m}^{-2} \mathrm{y}^{-1}\right)\end{array}$} \\
\hline 1.738 & Silt; $80 \mathrm{~m}$ & Northumberland, England & 1971 & Buchanan \& Warwick (1974) \\
\hline 13.3 (dry weight) & Mud; $<1 \mathrm{~m}$ & Lynher Estuary, Cornwall, England & $1972-1973$ & Warwick \& Price (1975) \\
\hline
\end{tabular}

of $0.0013 \mathrm{mg} \mathrm{AFDW} \mathrm{d}{ }^{-1} ; M$. gracillima rate $=0.032$ to $0.05 \mathrm{mg} \mathrm{AFDW} \mathrm{d}^{-1}$ (see Table 3, Stancyk et al. 1994)]. See Sköld et al. (1994, p. 88) for further discussion of regeneration rates of $A$. filiformis. However, $1.24 \mathrm{~g}$ AFDW $\mathrm{m}^{-2} \mathrm{yr}^{-1}$ may be an underestimate of trophic transfer, because the tips of the brittlestar arms are repeatedly grazed and a one-time estimate of percentage of biomass as regenerating tissue does not yield information on repetitive grazing events.

Historically, ophiuroids have probably been very important agents of benthic-pelagic coupling. Dense brittlestar beds are found in many areas of the ocean (commonly over $1000 \mathrm{~m}^{-2}$; Kunitzer 1989) and ophiuroids are frequently the biomass dominants in benthic habitats (e.g. Petersen 1915 cf. Thorson 1957, Barnard \& Ziesenhenne 1961, Buchanan 1964, Rosenberg et al. 1986, Steimle 1990). However, their energetic role has been largely unappreciated by benthic ecologists (Stancyk et al. 1994).

The role of sublethal predation in energy flow studies has also been generally ignored. Traditional models and estimates of energy flow or secondary production including the benthos do not include a sublethal predation component (e.g. Steele 1974, Yablonskaya 1979, Baird \& Ulanowicz 1989, Baird et al. 1991, Table 3 of Maurer et al. 1992 and references cited therein). Here we demonstrate that energy flow in North Inlet, due to sublethal grazing of Microphiopholis gracillima arm tissue alone, represents a significant trophic pathway which is comparable to whole community total secondary production in other benthic systems. Additionally, the potential amount of energy that could be transferred via this sublethal trophic pathway is obviously much greater in systems with higher abundance of amphiurid brittlestars, e.g. Bis- cayne Bay, Florida, USA (M. gracillima, $56 \mathrm{~m}^{-2}$; Singletary 1980); Mississippi Sound, Alabama, USA (M. atra, $1382 \mathrm{~m}^{-2}$; US Army Corps of Engineers 1982); or Galway Bay, Ireland (Amphiura filiformis, $1000 \mathrm{~m}^{-2}$; $\mathrm{O}^{\prime}$ Connor et al. 1986). With this evidence of $M$. gracillima as a trophically significant energy source to predators of major ecological and economic significance, we have demonstrated that sublethal predation on brittlestars or other grazed species should no longer be overlooked.

Acknowledgements. We thank R. M. Showman and J. M. Sodetz for their critical reviews of this manuscript. Assistance with field collection and experiments was provided by $D$. Eddins, D. Hoskins, S. Lindsay, C. Lindstrom, L. Lowry, G. Matsui, B. Sharer, P. Walters, and R. Woods. Assistance with dissection of fish, shrimp and crabs was provided by L. Barrineau and $\mathrm{M}$. Barber. Statistical advice was provided by $\mathrm{H}$. Finch, through the Statistical Consulting Laboratory, Department of Statistics, University of South Carolina. We are grateful to the Belle W. Baruch Institute for Marine Biology and Coastal Research and its staff for assistance and the use of facilities. Partial funding was provided by Sigma Xi Grantsin-Aid and the Slocum-Lunz Foundation. This is contribution no. 1131 of the Belle W. Baruch Institute for Marine Biology and Coastal Research.

\section{LITERATURE CITED}

Baird D, McGlade JM, Ulanowicz RE (1991) The comparative ecology of six marine ecosystems. Phil Trans R Soc Lond $333: 15-29$

Baird D, Ulanowicz RE (1989) The seasonal dynamics of the Chesapeake Bay. Ecol Monogr 59:329-364

Barnard JL, Ziesenhenne FC (1961) Ophiurord communities of southern California coastal bottoms. Pacif Nat 2 $131-1.52$

Bourgoin A (1987) Ecologie et demographie d'Acrocnida braciata (Montagu) (Echinodermata: Ophiuroidea) en Baie de 
Douarnenez (Bretagne). PhD dissertation, Universitié de Bretagne Occidentale, Brest

Bowmer T, Keegan BF (1983) Field survey of the occurrence and significance of regeneration in Amphiura filiformis (Echinodermata: Ophiuroidea) from Galway Bay, west coast of Ireland. Mar Biol 74:65-71

Buchanan JB (1964) A comparative study of some features of the biology of Amphiura filiformis and Amphiura chiajei (Ophiuroidea) considered in relation to their distribution J Mar Biol Assoc UK 44:565-576

Buchanan JB, Warwick RM (1974) An estimate of benthic macrofaunal production in the offshore mud of the Northumberland coast. J Mar Biol Ass UK 54:197-222

Clements LAJ (1985) Post-autotomy feeding behavior of Microphiopholis gracillima (Stimpson): implications for regeneration. In: Keegan BF, O'Connor BDS (eds) Echinodermata. Proceedings of the 5th International Echinoderms Conference, Galway, Ireland. Balkema, Rotterdam p 609-615

Clements LAJ, Bell SS, Kurdziel JP (1994) Abundance and arm loss of the infaunal brittlestar Ophiophragmus filograneus (Echinodermata: Ophiuroidea), with an experimental determination of regeneration rates in natural and planted seagrass beds. Mar Biol 118:451-462

Clements LAJ, Stancyk SE (1984) Particle selection by the burrowing brittlestar Microphiopholis gracillima (Stimpson) (Echinodermata: Ophiuroidea). J Exp Mar Biol Ecol 84:1-13

De Vlas J (1979a) Annual food intake by plaice and flounders in a tidal flat area in the Dutch Wadden Sea, with special reference to consumption of regenerating parts of macrobenthic prey. Neth J Sea Res 13:117-153

De Vlas J (1979b) Secondary production by tail regeneration in a tidal flat population of lugworms (Arenicola marina), cropped by flatfish. Neth J Sea Res 13:362-393

De Vlas J (1985) Secondary production by siphon regeneration in a tidal flat population of Macoma balthica. Neth J Sea Res 19:147-164

Duineveld GCA, Van Noort GJ (1986) Observations on the population dynamics of Amphiura filiformis (Ophiuroidea: Echinodermata) in the southern North Sea and its exploitation by the dab. Limanda limanda. Neth J Sea Res 20:85-94

Feder HM, Jewett SC (1981) Feeding interactions in the eastern Bering Sea with emphasis on the benthos. In: Hood DW, Calder JA (eds) The Eastern Bering Sea Shelf: oceanography and resources, Vol 2. NOA.A, University of Washington Press, Seattle, p 1229-1261

Feder HM, Jewett SC (1987) The subtidal benthos. In: Hood DW, Zimmerman ST (eds) The Gulf of Alaska. Physical environment and biological resources. United States Ocean Assessments Division, Alaska Office, United States Mineral Management Service, Alaska OCS Region, MMS 86-0095, US Government Printing Office, Washington, DC, p 347-396

Feder HM, Pearson TH (1988) The benthic ecology of Loch Linnhe and Loch Eil, a sea-loch system on the west coast of Scotland. V. Biology of the dominant soft-bottom epifauna and their interaction with the infauna. J Exp Mar Biol Ecol 116:99-134

Feller RJ, Taghon GL, Gallagher ED, Kenny GE, Jumars PA. (1979) Immunological methods for food web analysis in a soft-bottom benthic community. Mar Biol 54:61-74

Harvell CD (1984) Why nudibranchs are partial predators: intracolonial variation in bryozoan palatability. Ecology $65: 716-724$

Harvell CD, Suchanek TH (1987) Partial predation on tropical gorgonians by Cyphoma gibbosum (Gastropoda). Mar Ecol Prog Ser 38:37-44

Hendler GL (1973) Northwest Atlantic amphiurid brittlestars, Amphioplus abditus (Verrill), and Amphioplus sepultus N. Sp. (Ophiuroidea: Echinodermata): systematics, zoogeography annual periodicities and larval adaptations. PhD dissertation, The University of Connecticut

Hill BJ, Wassenberg TJ (1992) Preferences and amount of food eaten by the prawn Penaeus esculentus over the molt cycle. Aust J Mar Freshwat Res 43:727-35

Hunter J, Feller RJ (1987) Immunological dietary analysis of two penaeid shrimp species from a South Carolina tidal creek. J Exp Mar Biol Ecol 107:61-70

Jackson JBC. Palumbi SR (1979) Regeneration and partial predation in cryptic coral reef environments: preliminary experiments on sponges and ectoprocts. In: Levi C, BourgEsnalt N (eds) Biologie des spongiaires. Centre National de la Recherche, Paris, p 303-309

Josefson AB, Jensen JN (1992) Growth patterns of Amphiura filiformis support the hypothesis of organic enrichment in the Skagerrak-Kattegat area. Mar Biol 112:615-624

Kamermans P, Huitema HJ (1994) Shrimp (Crangon crangon L.) browsing upon siphon tips inhibits feeding and growth in the bivalve Macoma balthica (L.). J Exp Mar Biol Ecol 175:59-75

Kunitzer A (1989) Factors affecting the population dynamics of Amphiura filiformis (Echinodermata: Ophiuroidea) and Mysella bidentata (Bivalvia: Galeommatacea) in the North Sea. In: Ryland J, Tyler P (eds) Reproduction, genetics and distributions of marine organisms. Olsen and Olsen. Fredensborg, p 395-406

Lasker HR (1985) Prey preferences and browsing pressure of the butterflyfish Chaetodon capistratus on Caribbean gorgonians. Mar Ecol Prog Ser 21:213-220

Mattson S (1992) Food and feeding habits of fish species over a soft sublittoral bottom in the Northeast Atlantic. 3. Haddock (Melanogrammus aeglefinus (L.))(Gadidae). Sarsia $77: 33-45$

Maurer D, Howe S, Leathem W (1992) Secondary production of macrobenthic invertebrates from Delaware Bay and coastal waters. Int Rev Gesamten Hydrobiol 77 : $187-201$

Moller P, Pihl L, Rosenberg R (1985) Benthic faunal energy flow and biological interaction in some shallow marine soft bottom habitats. Mar Ecol Prog Ser 27:109-121

O'Connor B, Bowmer T, McGrath D, Raine R (1986) Energy flow through an Amphiura filiformis (Ophiuroidea: Echinodermata) population in Galway Bay, west coast of Ireland: a preliminary investigation. Ophelia 26 : 351-357

Ogburn MV, Allen DM, Michener WK (1988) Fishes, shrimps, and crabs of the North Inlet Estuary, SC: a four-year seine and traw] survey. Baruch [nstitute Technical Report No. 88-1 University of South Carolina Press, Columbia

Pape-Lindstrom PA (1994) A laboratory and field study of sublethal predation on the brittlestar, Microphiopholis gracillima (Stimpson) (Echinodermata: Ophiuroidea), by white shrimp and other macerating predators: an immunochemical approach. PhD dissertation, University of South Carolina

Petersen CGJ (1915) On the animal communities of the sea bottom in the Skagerrak, the Christiana Fjord and the Danish waters. Rep Dan Biol Stn 23:3-28

Peterson CH, Quammen ML (1982) Siphon nipping: its importance to small fishes and its impact on the growth of the bivalve Protothaca staminea (Conrad). J Exp Mar Biol Ecol $63: 249-268$ 
Pihl L (1985) Food selection and consumption of mobile epibenthic fauna in shallow marine areas. Mir Ecol Prog Ser 22:169-179

Rosenberg R, Gray JS, Josefson AB, Pearson TH (1986) Petersen's benthic stations revisited. II. Is the Uslofjord and eastern Skagerrak enriched? J Exp Mar Biol Ecol 105 $219-252$

SAS Institute Inc. (1988) SAS/STAT user's gujde, release 603 edition. SAS Institute, Inc, Cary, NC

Singletary RL (1980) The biology and ecology of Amphioplus coniortodes. Ophionephys limicola and Microphiopholis gracillima (Ophiuroidea: Amphiuridae). Caribb J Sci 16: $39-55$

Sköld M, Loo LO, Rosenberg R (1994) Production, dynamics and demography of an Amphiura filiformis population. Mar Ecol Prog Ser 103:81-90

Sköld M, Rosenberg R (1996) Arm regeneration frequency in eight species of Ophiuroidea (Echinodermata) from European sea areas. J Sea Res 35:353-362

Stancyk SE, Golde HM, Pape-Lindstrom PA, Dobson WE (1994) Born to lose: I. Measures of sublethal loss and regeneration by the brittlestar, Microphiopholis gracillima (Stimpson) (Echinodermata: Ophiuroidea) in the freld and laboratory. Mar Biol 118:451-462

Steele JH (1974) The structure of marine ecosystems. Harvard University Press, Cambridge, MA

Steimle FW (1990) Benthic macrofauna and habitat monitoring on the continental shelf of the northeastern United States. I. Biomass. NOAA Tech Rep NMFS 86, US Dept of Commerce

Theiling D (1988) Assessment of participation and resource impact of shrimp baiting in coastal. South Carolina dunng 1987. South Carolina Marine Resources Center, Technical Report No. 69, South Carolina Wildlife and Marine Resources Department

Thorson G (1957) Bottom communities. In: Hedgepeth JW (ed) Treatise on marine ecology and paleoecology, Vol 1, Ecology. Geol Soc Am Mem 67. p 461-534

This article was presented by Kenneth Tenore (Senior Editorial Advisor), Solomons, Maryland, USA
Trevallion A (1971) Studies on Tellina tenuis da Costa III Aspects of general biology and energy flow. I Exp Mar Biol Ecol 7:95-122

US Army Corps of Engineers (1982) Final report. Benthic macroinfauna community characterizations in Mississippi Sound and adjacent waters. US Army Corps of Engineers, Contract no. DACW01-80C427

Valentine JF (1991) Temporal variation in populations of the brittlestars Hemipholis elongata (Say, 1825) and Microphiopholis atra (Stimpson, 1852) (Echinodermata: ()phiuroidea) in eastern Mississippi Sound. Bull Mar Sci 48:597-605

Warwick RM, Price R (1975) Macrofauna production in an estuarine mud-flat. J Mar Biol Assoc UK 55:1-18

Wassenberg TJ, Hill BJ (1987) Natural diet of the tiger prawns Penaeus esculentus and $P$. semisulcatus. Aust J Mar Freshwat Res 38:169-182

Woodin SA (1.984) Effects of browsing predators: activity changes in infauna following tissue loss. Biol Bull Mar Biol Lab Woods Hole 166:558-573

Woodley JD (1975) The behavior of some amphiurid brittlestars. J Exp Mar Biol Ecol 88:1-19

Yablonskaya EA. (1979) Studies of trophic relationships in bottom communities in the southern seas of the USSR In: Dunbar MJ (ed) Marine production mechanism. Cambridge University Press, Cambridge, p 285-316

Zajac RN (1985) The effects of sublethal predation on reproduction in the spionid polychaete Polydora ligni Webster. J Exp Mar Biol Ecol 88:1-19

Zajac RN (1995) Sublethal predation on Polydora cornuta (Polychaeta: Spionidae): patterns of tissue loss in a field population, predator functional response and potential demographic impacts. Mar Biol 123:531-541

Zamarro J (1992) Feeding behaviour of the American plaice (Hippoglossoides platessoides) on the southern Grand Bank of Newfoundland. Neth J Sea Res 29:229-238

Zwarts L, Wanink J (1989) Siphon size and burying depth in deposit- and suspension-feeding benthic bivalves. Mar Biol 100:227-400

Manuscript received: November 27, 1995

Revised version accepted: June 30, 1997 